\title{
RELATIONSHIP BETWEEN ECONOMIC GROWTH AND ENVIRONMENTAL PRESSURES (LEGAL ASPECTS)
}

\author{
Galyna V. Moroz*, Olga A. Grytsan, Oleh A. Vivcharenko, Nadiia R. Kobetska
}

Vasyl Stefanyk Precarpathian National University, Ivano-Frankivsk, Ukraine.

ART ICLE INFO

\section{Article History}

Received: April 21, 2021

Revised: July 1, 2021

Accepted: July 30, 2021

\section{Keywords}

Private interests

Public interests

Green economy

Legal aspect of nature

management

Environmental protection
A B S T R A C T

The problem of the impact of economic development of the world on the state of the environment is quite relevant today. Entrepreneurs usually defend their private interests and try to increase profits in every possible way, without caring about the state of the environment and the future. If in the economically developed countries of the world the government is trying hard to control compliance with environmental legislation and implement a green economy, Ukraine is hopelessly behind, and only in recent years is beginning to actively think about preserving the environment and develop mechanisms to achieve this goal. It is important to explore how the legal aspect can help address the balance between Ukraine's economic development and environmental quality, especially in terms of its impact on climate change, where air pollution, waste generation and energy security are key factors. The purpose of the study was to investigate the legal aspect of the interrelation between economic growth and environmental pressures. As a result, the world experience in finding ways of mutually beneficial activities for the economic development of countries and the preservation of the environment was analysed. The study examined the factors influencing climate change, waste generation and energy security in the projection of economic development. The main principles (strategy) of the state ecological policy of Ukraine for the period up to 2030 are analysed; regulations of Ukraine and the European Union, which regulate the preservation of the environment in terms of the legal effect on solving the problem of the interrelation between economic growth and pressure on the environment.

Corresponding Author: Galyna V. Moroz

Email: moroz6096@murdoch.in

(c) The Author(s) 2021.

\section{INTRODUCTION}

All environmental problems of the European Union and developed countries are also present in Ukraine. The difference is that abroad these issues are handled at the highest state level, and in Ukraine it is very often only at the level of volunteering and public organisations. The existing Ukrainian legislation is often simply not complied with, as it is not beneficial primarily for the private interests of the economic elite. The root causes of environmental problems in Ukraine are as follows
(Khvesyk and Stepanenko., 2014):

- the inherited structure of the economy with the predominant share of resource- and energyintensive industries, the negative impact of which intensified with the transition to market conditions;

- depreciation of fixed assets of industrial and transport infrastructure;

- the existing system of public administration in the field of environmental protection and regulation of the use of natural resources; 
- lack of clear delineation of environmental and economic functions;

- underdevelopment of civil society institutions;

- insufficient understanding of the priorities of environmental protection and the benefits of sustainable development in society;

- non-compliance with current environmental legislation.

One of the main causes of pollution is the constant conflict of interests between the economic and environmental components of development. Economic development of Ukraine, as well as in foreign countries, leads to many dangerous consequences, such as air pollution, climate change, greenhouse effect, ozone depletion, pollution of water and soil environment, the generation of household, industrial, and radioactive waste. At the same time, without significant investments in the greening of production processes, it is impossible to ensure the preservation of the environment. These entrepreneurs must allocate these funds from their profits, which is not in their interests. Thus, there is a constant conflict of interest. The only effective aspect of resolving this issue is the development and implementation of effective mechanisms of legislative and legal direction, which would clearly regulate the rules of action, as well as the introduction of an effective branch of executive power that would monitor their compliance.

To address the above issues, Ukraine and the world are developing "Action Plans", among which a special place is occupied by Environmental Development Strategies at the state and interstate levels, which essentially constitute the environmental policy of the countries involved. In this aspect, Ukraine has adopted the Law of Ukraine "On the Fundamental Principles (Strategy) of State Environmental Policy of Ukraine until 2030", which came into force on January 1, 2020 (The Law of Ukraine, 2019a). Together with other laws and regulations, this document should help reduce the anthropogenic burden on the environment. It is necessary to investigate how the legal aspect can contribute to solving the problem of balance between economic development of Ukraine and preservation of environmental quality, especially in the context of climate change, where air pollution, waste generation, and energy security play a major role.

\section{LITERATURE REVIEW}

\section{The analysis of national research on the subject}

Ukraine is a country where economic growth leads to rapid environmental pollution. Accordingly, there are problems of interaction of environmental and economic, as well as private and public interests. Therefore, the development and adoption of mechanisms that would promote the development of the economy with an effective focus on environmental protection is an urgent issue. Scientific article (Danylyshyn and Veklych, 2008) explores the concept of the process of decoupling as an economic phenomenon that demonstrates the potential of a particular economy to increase economic power without harming the environment. Based on the analysis of decoupling indicators in Ukraine and its regions, the authors of Sotnyk and Kulyk. (2014) conclude that Ukraine's economy is unbalanced in terms of environmental protection. Ukraine's economic growth is increasing with the anthropogenic pressure on the environment and the use of an increasing amount of natural resources. The authors developed recommendations for Ukraine and its regions to achieve the effect of decoupling as a strategic basis for moving towards an environmentally sustainable economy through significant changes in Ukrainian public policy, the pace of scientific and technological progress and structural changes in the economy.

An important aspect in the development of the balance between economic growth and environmental protection is the consideration of the legal component in research. The work Moroz (2019a) argues the need for new forms of protection of the rights and interests of a considerable number of people. In the context of the specifics of environmental disputes, this is extremely necessary. The institution of a class action should become an important legal mechanism to prevent violations in the field of protection of the rights and interests of participants in environmental legal relations. The article Moroz (2019b) substantiates the objective necessity of unconditional compliance with legally established environmental requirements, prohibitions and restrictions, and their scientifically substantiated strengthening to achieve ecologically important goals focused on the priorities of sustainable development. Restrictive mechanisms are scattered across regulations of different legal force and even different legal branches; therefore, to ensure a holistic system of environmental restrictions, the said restrictive mechanisms should be 
systematised and unified, while practical implementation experience should be generalised. According to the author, the conceptual principles and general essential features of public environmental requirements and restrictions should be reflected in the future Environmental Code of Ukraine. The article Moroz (2020) offers a conceptual understanding of the mechanism of institutionalisation of interests in environmental law as a multifaceted long process of development of such ecological and social order (state) in the form of established functional institutions within the socio-economic, political, and legal system, in the conditions of which there will be an adaptation of interests of individuals, collectives, and their groups to statutory requirements, transformation of abstract rules into real and effective models of stable interaction.

Article Goroshkova et al. (2019) analyses the model of the environmental Kuznets curve (EKC), which assumes an inverse relationship between per capita income and environmental quality. In particular, this analysis seeks to take into account the current globalisation process in order to determine the impact of progressive global economic integration on the relationship between economic growth and environmental degradation. It is proved that the EKC model clearly reflects the correctness of the hypothesis of the relationship between economic growth and environmental impact. Reduction of the impact on the environment through economic development is possible only through increased spending on environmental activities. The article proves that specialised companies that render environmental services are leaders in the top 15 countries of the European Union in terms of environmental investment. In less developed EU countries, the main source of environmental investment is the business sector, in second place - state and municipal funding (Poland).

The scientific article Kyshko-Yerli (2014) considers aspects of the ecological legislation of Ukraine, and especially its codification and adaptation to regulations of the countries of the European Union concerning environmental protection. Based on a comparative legal analysis of the experience of EU member states, the study substantiates the feasibility of adopting the Environmental Code of Ukraine. The study Yakushev (2016) examines the trends of environmental policy in Ukraine in terms of sustainable development management. The authors of the study cite international experience in this field and identify the main areas of environmental development in the decentralisation process. The existing issues of environmental protection and environmental policy in Ukraine are considered, researchers suggest taking into account the environmental component of sustainable development in the further reform of government by introducing a mechanism for effective solution of environmental problems by local communities. In the scientific article (Senyshyn and Senyshyn., 2017), the authors investigate the organisational and institutional principles of national targeted programming of environmental protection in Ukraine, analyse the legal documents in the field of environmental protection. The authors emphasise that the main tasks of the development of the national environmental policy of Ukraine are the creation of a new system of environmental legislation and the development of a state mechanism to ensure compliance with legal environmental requirements and their implementation into environmental legislation of the European Union.

\section{Research of foreign experts on intersection of economy and nature conservation}

An important stage of foreign research is the analysis of modern scientific approaches, mechanisms, directions to address the issue of effective interaction of economic processes and preservation of the quality of the environment. The thesis that society can separate economic growth, defined as growth of gross domestic product (GDP), from the growth of the burden on the environment is quite tempting. However, if such a separation is possible, it means that GDP growth is a stable social goal.

The study James et al. (2016) notes that the concept of separation can be interpreted using a model of economic development and environmental impact. This model is compared with historical data and simulated forecasts to demonstrate that GDP growth ultimately cannot be separated from the use of materials and energy. Thus, the development of a policy focused on growth and possible segregation is erroneous. GDP growth can lead to improved welfare of the world's population, but at the same time it leads to considerable environmental pollution.

In recent decades, economic growth and the welfare of people around the world have been driven by the rapidly growing use of natural resources (including materials 
and energy) and carbon emissions, which have simultaneously reduced resource security, volatile natural resource prices and climate change. The task was to investigate whether a well-thought-out policy could reduce the global use of materials and energy. A new approach of combined economic and environmental modelling was used to assess the potential of division in 13 regions of the world using a production (territorial) approach, as well as a consumption approach to discuss regional differences in the use of natural resources (Schandl et al., 2016). Carbon emissions were analysed in three stylised policy perspectives: a reference case without significant changes in environmental and climate policy; "high efficiency" forecast, which predicts an increase in the global price of carbon from 50 to 236 US dollars (at a constant price) per tonne of $\mathrm{CO} 2$ in the period from 2010 to 2050 and efficiency increase in resource consumption (increase from 1.5\% historically to $3.5-4.5 \%$ in scenarios); forecast "medium efficiency", intermediary between the "without changes" and "high efficiency" forecasts. The results are reflected in the full text of the study. A similar study was conducted in the article (Yadong et al., 2017). The UN Sustainable Development Goals for 2030 are set, on the one hand, to address inclusive growth and poverty reduction, and on the other hand, to preserve the environment. The correlation between development and the environment has been widely investigated since the 1990s, documenting the inverted U-shaped relationship between per capita income and environmental degradation rates. The results of the study (Schandl et al., 2016) confirm that the efficiency of non-renewable resources of the Earth is gradually increasing, but mere increase in efficiency is insufficient to compensate for the increase in the scale of losses.

Understanding how the circular economy (CE) can reduce environmental pressures from economic activity is crucial for policy and practice. Science offers certain indicators for monitoring and evaluating the activities of CE. However, the overall activities of the CE, namely recycling and green design, are examined in terms of contribution to environmental sustainability. The study (Yadong et al., 2017) estimates the extent to which modern approaches to the evaluation of CE activities cover environmental pressures to monitor progress towards environmental sustainability. Based on the flow of materials, the authors demonstrate that most indicators do not take into account the environmental pressures associated with the CE activities under consideration. Many people focus on a single CE activity or process, which does not necessarily increase environmental sustainability in general. Based on these results, the authors propose to supplement the management indicators of CE with indicators that record the main environmental pressures associated with the relevant activities of CE. Given the conceptual relationship between CE activities, resource extraction and waste streams, it can be assumed that a resourcebased approach that takes into account key environmental contributions and outputs is necessary to assess the environmental sustainability of CE activities. Article (Hatfield-Dodds et al., 2015) notes that more than two centuries of economic growth have put undeniable pressure on the ecological systems that underpin human well-being. While everyone agrees with the fact that the pressure is rising, opinions differ on how to reduce it. Using Australia as an example, authors consider a new comprehensive analysis of the relationship between energy, water and food, rural land use (including biodiversity), material flows, and climate change to see if Australia's growing environmental pressures can be reduced while population growth and welfare increase. The study demonstrates that under the right circumstances, economic and environmental results can be separated. Although economic growth is high in all scenarios, environmental performance is fundamentally different: pressures are projected to more than double, stabilise, or fall significantly by 2050 . However, there is little evidence that the division will happen naturally, and therefore will require significant efforts, including political and legislative ones.

Based on Solow's growth model, a combinatorial model of economic growth under environmental pressure is developed (Dai et al., 2013). Using this model, it is possible to calculate the optimal number of industries in the economy, and the term "optimal number" can be considered as a criterion for decision-making on industry segmentation. This study presents the critical value of the number of industries in the economy, which determines the growth (or reduction) of economic output after industrial segmentation. The results obtained include: firstly, technological progress and innovative growth cause segmentation of the industry; secondly, industry segmentation is the main approach to supporting economic growth under environmental pressures. 
Thus, the analysis of literature sources indicates a constant scientific search for mechanisms to solve the problem of finding a balance between economic growth in the world and the preservation of the environment. World scientists and professional ecologists are constantly trying to develop mechanisms that would promote the rational use of nature. Admittedly, it is important to take into account the legal aspect on the way to achieving the result.

\section{MATERIALS AND METHODS}

This study employed theoretical research methods, namely the analysis of domestic and foreign literature sources, which considered a wide scope of current environmental issues and matters of approaches to environmentally oriented economic activities, as well as the legal component in this process. The material basis of the study of the said legal component included the Constitution of Ukraine, the Laws of Ukraine on Environmental Protection, the Directives of the European Parliament and the Council of Europe, which are aimed at preserving the environment. The theoretical framework of the study included the articles of scientists in the field of ecology, environmental management, economics, and legal science. The study is based on the general principles of scientific cognition, namely system analysis, which establishes logical structural relationships between the studied elements, process analysis, which allows to consider a holistic picture based on a set of elements under study and scientific objectivity.

The methodological framework of the study comprises a system of general and special methods of scientific cognition.

General methods include comparison based on the results of primary data processing, factor analysis to identify causal relationships, and elementary theoretical analysis and synthesis. The use of general scientific methods of formal logic was conditioned by the need to investigate the mechanisms of development of legal provisions and search for factors that can, by themselves or consequentially, provoke deterioration of agricultural land, reduction of forest-steppe and river areas, and environmental pollution, caused by such factors as incorrect waste disposal and air pollution. This, in turn, will provoke the application of current legislation to violators and the possible prosecution of guilty individuals and legal entities. The empirical basis of the study included data obtained from the analysis and synthesis of information contained in various sources of reporting, including environmental control bodies and bodies of control over violations committed by individuals and legal entities. The research procedure can be represented as a system model of the algorithm presented in Figure 1.

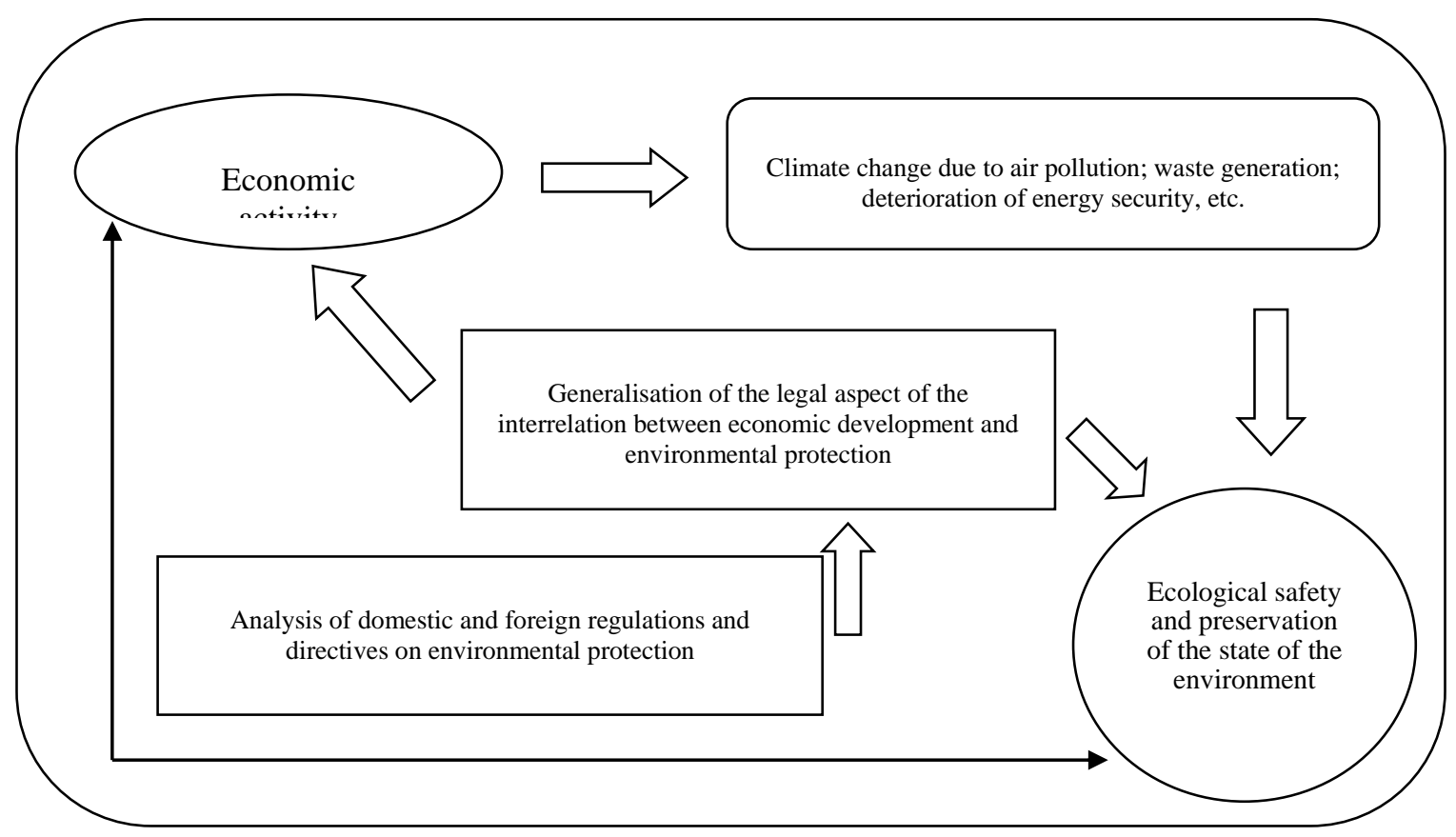

Figure 1. System model of research algorithm. 


\section{RESULTS AND DISCUSSION}

The world and humanity are at a crucial stage in their development with regard to climate change. In the last three years alone, global economic losses from climate change have amounted to 1 trillion US dollars. In the long run, an increase in global temperature by 2-4 degrees means catastrophic consequences. NASA research indicates that since the middle of the last century, the level of carbon dioxide concentration has become higher than in the last 650,000 years. Admittedly, the concentration of $\mathrm{CO}_{2}$ has never been kept at the same level: like everything in nature, this process is cyclical. But in the given situation, this is a precedent for such a sharp rise that it continues to gain momentum. Scientists have proved that it is human activity that causes the catastrophic melting of glaciers in Greenland, the Arctic, Antarctica, while other parts of the world suffer from floods and droughts. Recent data indicate that in this decade, warming is 10 times faster than before.

This is all a global picture, but Ukraine is not left out. The country is already losing money due to abnormal weather conditions caused by global warming. Considering the case of elementary annual downpours and squalls, the probability that over time the frequency and severity of these dangerous weather events will only increase is greater than ever. Along with the intensified occurrence of tornadoes, which were not previously inherent in the territory of Ukraine, strong hurricanes become more frequent, tearing down the roofs of buildings and uprooting trees. Climatic anomalies such as chicken egg-sized hail or prolonged downpours alternating with two-month droughts have also become commonplace.

Due to rising ocean levels, flooding or total extinction of coastal areas is predicted. Cities such as Hola Prystan, Zatoka, Lazurne will be completely submerged. Ukrainian Venice - the city of Vylkove on the Danube will disappear in about 50 years. Large cities - Odesa, Mykolaiv, Kherson, Mariupol, Berdiansk, Kerch - will also suffer. Tens, if not hundreds, of thousands of people will be forced to flee their homes. Thus, Ukraine will have to deal with another wave of internally displaced persons. Lack of drinking water will also become a problem. The situation is projected to be particularly serious in large cities. Prolonged droughts will cause rivers to flow, necessitating the search for new sources of water or, in general, austerity of water resources, including the provision of water on schedule and the restriction of water intake for businesses.

At the same time, in the south of Ukraine there is a complete degradation of lands and steppes. Soon the entire Southern Ukraine will become Oleshky Sands. Therewith, Ukrainian forests occupy only 16\% of the country's territory, but they will also disappear from infectious diseases and a record number of pests. Even now, the spread of microorganisms through warming is leading to the mass extinction of coniferous forests, and if the use of hydrocarbons continues, in a few decades' forests may not remain in Ukraine at all. Warming will lead to increased soil erosion. At present, Ukraine annually loses fertile chernozem. Excessive and frequent droughts will increase the destructive effect. Ukrainian agriculture, on the one hand, is capable of developing new crops and harvesting two crops a year, but the benefits end there. Farmers will be forced to invest in irrigation systems in the absence of water resources, carry out spring field work faster, protect crops from new pests and unpredictable weather anomalies such as hail, which can destroy crops altogether.

The situation with solid household and industrial waste in Ukraine also cannot be described positively. According to the State Statistics Service, the amount of accumulated waste currently exceeds 12 billion tonnes. According to unofficial sources - three times more. Last year alone, according to the Ministry of Regional Development, about 10 million tonnes of waste were created, which were buried in 6,000 waste deposits and landfills with a total area of over 9,000 hectares. In addition, there are tens of thousands of landfills in the private sector with an area of thousands of hectares, which is almost impossible to measure accurately. Thus, according to the Ministry of Regional Development, about 28 thousand unauthorised landfills are detected annually. According to environmentalists, most landfills often operate without any legal regulation, violating existing provisions and standards. The result was a catastrophe in Hrybovychi, the largest landfill in the Lviv Oblast, which was obsolete and already overflowing with waste. Because of shift of several tons of waste, some people got caught under the rubble. The solution to the situation also turned out to be far from effective: to transport waste to the Kyivska Oblastand burn it at the Energia plant, which is already operating at full capacity. This example clearly demonstrates that waste management problems should be addressed before they 
occur. To this end, a national strategy for waste management and investment in recycling plants must be developed. In general, only $4 \%$ of household waste in Ukraine is recycled at incinerators that generate positive energy. This is a meagre number on a national scale. Firstly, there is no infrastructure for separate collection, sorting, and disposal of solid waste. This significantly reduces the level of processing and disposal, and accordingly increases the level of their burial. Secondly, there are significant problems in the legislation related to household waste. In general, Ukraine lacks a national strategy to address littering. In addition, the Ministry of Ecology and Natural Resources noted that a framework law on waste management is currently being drafted, which should become the cornerstone of reforming the system and establishing a system of terminology, as well as basic principles of waste management in accordance with EU law.

At the same time, in the EU, the rate of use of materials per person is 16 tonnes, of which 6 become waste. Each of the EU's 500 million households generates an average of half a tonne of household waste a year as part of household waste. In total, the EU produces about 3 billion tonnes of waste per year - $40 \%$ of which is reused or recycled. Therewith, the solid waste management and processing industries in the EU have a turnover of 137 billion euros, which is slightly more than $1.1 \%$ of total GDP. Together, these areas create 2 million jobs. If EU member states recycle $70 \%$ of their waste, it will create another 500,000 new jobs within the EU. The directive is the recycling of $50 \%$ of municipal waste and $70 \%$ of construction waste by 2020 . Across the EU, the share of waste deposits should be reduced to $30 \%$ and the share of waste for incineration - to 20\%. By 2050, up to $100 \%$ of waste should be recycled. At present, about $40 \%$ of waste goes to waste deposits, $40 \%$ is recycled or composted, and the rest is incinerated. The leaders in recycling are Germany, the Netherlands, and Austria, where about $70 \%$ of waste is recycled. Sweden, Denmark, Belgium, and Luxembourg have slightly lower rates. In terms of energy security, it is worth mentioning the depletion of Ukraine's natural non-renewable resources. Most energy companies in Ukraine run on coal, which is rapidly depleting. In addition, a considerable part of the deposits is located in the territory beyond Ukraine's control, which impairs access to resources. On the other hand, coal combustion has an extremely negative effect on the state of the atmosphere, because during this process a considerable amount of oxides of sulphur and carbon monoxide and carbon dioxide is released. Another problem of Ukraine's energy security is its dependence on energy imports. Each of the above issues is a consequence of the rapid development of the economy. One of the ways to solve this problem is the active use of the legal mechanism. At present, one of the fundamental legal documents in Ukraine is the Law of Ukraine "On Fundamental Principles (Strategy) of State Environmental Policy of Ukraine until 2030"(The Law of Ukraine, 2019b). The basic principles of the national environmental policy of Ukraine are presented in Fig. 2, and the objectives are presented in Table 1. Table 2 presents information on the existing and prognostic results of the implementation of the principles of the national environmental policy of Ukraine on the basis of 2015 (The Law of Ukraine, 2019a).

Table 1. Goals of the state ecological policy of Ukraine

\begin{tabular}{ll}
\hline No. & Goal \\
\hline 1 & Development of ecological values and principles of sustainable consumption and production in society \\
2 & $\begin{array}{l}\text { Ensuring sustainable development of Ukraine's natural resource potential } \\
3\end{array}$ \\
$\begin{array}{l}\text { Ensuring the integration of environmental policy in the decision-making process for socio-economic } \\
\text { development of Ukraine }\end{array}$ \\
4 & $\begin{array}{l}\text { Reduction of environmental risks in order to minimise their impact on ecosystems, socio-economic } \\
\text { development, and public health }\end{array}$ \\
5 & Improvement and development of the state system of environmental management \\
\hline
\end{tabular}

The next effective legislative document of Ukraine in the field of environmental protection is the Law of Ukraine "On Environmental Impact Assessment" (The Law of Ukraine, 2017). The law establishes the legal and organisational framework for environmental impact assessment aimed at preventing environmental damage, ensuring environmental safety, environmental protection, rational use and reproduction of natural 
resources in the decision-making process of economic activities that may have a significant impact on the environment, considering national, public, and private interests.

\begin{tabular}{|c|}
\hline The main principles of national environmental policy \\
\hline $\begin{array}{l}\text { Retention of a state of the climate system that would make it impossible to increase the risks to human } \\
\text { health and well-being and the environment }\end{array}$ \\
\hline $\begin{array}{l}\text { Ukraine's achievement of the Sustainable Development Goals (SDGs), approved at the } 2015 \text { United } \\
\text { Nations Summit on Sustainable Development }\end{array}$ \\
\hline $\begin{array}{l}\text { Promotion of balanced (sustainable) development by achieving balanced components of development } \\
\text { (economic, environmental, social), focusing on the priorities of balanced (sustainable) development }\end{array}$ \\
\hline $\begin{array}{l}\text { Integration of environmental requirements during the development and approval of documents of state } \\
\text { planning, industrial (sectoral), regional, and local development and in the decision-making process } \\
\text { regarding the planned activities of facilities that may have a substantial impact on the environment }\end{array}$ \\
\hline Cross-sectoral partnership and stakeholder involvement \\
\hline $\begin{array}{l}\text { Prevention of emergencies of natural and anthropogenic origin, which involves the analysis and } \\
\text { forecasting of environmental risks, based on the results of strategic environmental assessment, } \\
\text { environmental impact assessment, as well as comprehensive monitoring of the environment }\end{array}$ \\
\hline $\begin{array}{l}\text { Ensuring environmental safety and maintaining ecological balance in Ukraine, increasing the level of } \\
\text { environmental safety in the exclusion zone }\end{array}$ \\
\hline Ensuring the inevitability of liability for violations of environmental legislation \\
\hline $\begin{array}{l}\text { Application of the principles of precaution, prevention, priority of eliminating sources of environmental } \\
\text { damage, the Polluter-Pays-Principle }\end{array}$ \\
\hline $\begin{array}{l}\text { Responsibility of executive authorities and local governments for the availability, timeliness, and } \\
\text { reliability of environmental information }\end{array}$ \\
\hline $\begin{array}{l}\text { Government stimulation of domestic business entities that reduce greenhouse gas emissions, reduce } \\
\text { energy and resource intensity, modernise production aimed at reducing the negative impact on the } \\
\text { environment, including improvement of the environmental tax system for environmental pollution and } \\
\text { payments for the use of natural resources }\end{array}$ \\
\hline Id forms of communications and effective information policy in the \\
\hline
\end{tabular}

Figure 2. Basic principles of the national ecological policy of Ukraine. 
Table 2. Indicators for assessing the implementation of the principles of national environmental policy

\begin{tabular}{|c|c|c|c|c|c|}
\hline \multirow{2}{*}{ Indicator } & \multirow{2}{*}{ Unit of measurement } & \multicolumn{4}{|c|}{ Target values } \\
\hline & & 2015 & 2020 & 2025 & 2030 \\
\hline $\begin{array}{l}\text { Share of renewable energy sources } \\
\text { (including hydropower and thermal } \\
\text { energy) }\end{array}$ & percent of total energy consumption & 4 & 8 & 12 & 17 \\
\hline Proportion of landfilled waste & $\begin{array}{l}\text { percent of the total amount of waste } \\
\text { generated }\end{array}$ & 50 & 45 & 40 & 35 \\
\hline Volumes of use of primary raw materials & percent of total raw materials used & 90 & 85 & 80 & 75 \\
\hline Greenhouse gas emissions & $\begin{array}{l}\text { percent of greenhouse gas emissions in } \\
1990\end{array}$ & 37.8 & $<76$ & $<60$ & $<60$ \\
\hline $\begin{array}{l}\text { Emissions of pollutants into the } \\
\text { atmosphere from stationary sources }\end{array}$ & percent of emissions in 2015 & 100 & $<6$ & $<16.5$ & $<22.5$ \\
\hline
\end{tabular}

Environmental impact assessment is carried out in compliance with the requirements of environmental legislation, taking into account the state of the environment in the place where the planned activities are to be carried out, environmental risks and forecasts, prospects for socio-economic development of the region, capacity, and aggregate (direct and indirect) impact on the environment, including consideration of the impact of existing facilities, planned activities, and facilities in respect of which a decision has been made to carry out the planned activities or the issue of making such decisions is being considered. In the process of environmental impact assessment, timely, adequate, and effective public information is provided. Environmental Impact Assessment (EIA) Principles regulate the notice of the planned activity that is subject to environmental impact assessment, the announcement of the beginning of public discussion of the environmental impact assessment report, informing about the conclusion on the environmental impact assessment and the decision to conduct the planned activity as follows:

- the use of EIA as a tool for decision-making in the initial stages of design and the availability at the same stages of information on design solutions to the public;

- consideration in the relationship of technological, technical, social, environmental, and economic indicators of project proposals;

- alternative design solutions, development of new alternatives;

- responsibility of the customer (initiator) of activity for consequences of implementation of design decisions. Apart from analysing national legislation, the study should focus on the analysis of European Union Directives.

Table 3 demonstrates the main Directives of the European Union, which govern the protection of the environment. In addition to the problems described in detail above, below are some other documents that are strategically important in the aspect of Ukraine's cooperation with the European Union.

Table 3. European Union directives.

\begin{tabular}{ll}
\hline \multicolumn{1}{c}{ Sector } & \multicolumn{1}{c}{ Directive (regulation)* } \\
\hline Climate Change and & Directive 2003/87/EC establishing a scheme for greenhouse gas emission allowance trading \\
Ozone Protection & within the Community \\
\cline { 2 - 2 } Sector & EU Regulation No 842/2006 on certain fluorinated greenhouse gases \\
\cline { 2 - 2 } & EU Regulation No 2037/2000 on substances that deplete the ozone layer \\
\hline "Environmental & Directive 2003/4/EC on public access to environmental information \\
\cline { 2 - 2 } $\begin{array}{l}\text { management and } \\
\text { integration } \\
\text { environmental of } \\
\text { policy into other } \\
\text { industrial policies" }\end{array}$ & $\begin{array}{l}\text { Directive 2011/92/EU on the assessment of the effects of certain public and private projects } \\
\text { on the environment }\end{array}$ \\
\cline { 2 - 2 } & $\begin{array}{l}\text { Directive 2001/42/EC on the assessment of the effects of certain plans and programmes on } \\
\text { the environment }\end{array}$ \\
\hline Atmospheric Air & $\begin{array}{l}\text { Directive 2003/35/EC providing for public participation in respect of the drawing up of } \\
\text { certain plans and programmes relating to the environment }\end{array}$ \\
\cline { 2 - 2 } Quality Sector & Directive 2008/50/EC on ambient air quality and cleaner air for Europe \\
\cline { 2 - 2 } &
\end{tabular}


aromatic hydrocarbons in ambient air

Directive 98/70/EC relating to the quality of petrol and diesel fuels

Directive 1999/32/EC relating to a reduction in the sulphur content of certain liquid fuels

Directive 94/63/EC on the control of volatile organic compound (VOC) emissions resulting

from the storage of petrol and its distribution from terminals to service stations

Directive 2004/42/EC on the limitation of emissions of volatile organic compounds due to the use of organic solvents in certain paints and varnishes and vehicle refinishing products

Waste and

Directive 2008/98/EC on waste (Framework Directive)

Resource Directive 1999/31/EC on the landfill of waste

Management Sector Directive 2006/21/EU on the management of waste from extractive industries

Note: * All the following EU directives are available on the EUR-Lex website. Access to European Union Law: https://eur-lex.europa.eu/homepage.html

It is worth exploring how the legal documents of Ukraine relate to the Directives and Regulations of the European Union:

1) Climate change. To develop an effective domestic climate policy, the Cabinet of Ministers of Ukraine approved the Concept for the implementation of national policy in the field of climate change until 2030 (State Climate Change Policy, 2016). On July 18, 2018, the protocol decision of the meeting of the Cabinet of Ministers of Ukraine approved the proposal of the Ministry of Environment to submit the Strategy of Low Carbon Development of Ukraine until 2050 to the Secretariat of the UN Framework Convention on Climate Change. On July 30, 2018, this Strategy was posted on the website of the Secretariat of the UN Framework Convention on Climate Change (The Low Carbon Development Strategy of Ukraine, 2016). The Law of Ukraine "On Monitoring, Reporting, and Verification of Greenhouse Gases" adopted to implement certain provisions of Directive 2003/87/EC and the Law of Ukraine "On Regulation of Economic Activities with Ozone Depleting Substances and Fluorinated Greenhouse Gases" adopted with consideration of provisions of the EU Regulation No 842/2006 and EU Regulation No 2037/2000, aimed at regulating legal relations concerning the production, import, export, storage, use, placing on the market and handling of ozone-depleting substances, fluorinated greenhouse gases, goods and equipment containing or using them, which affects the ozone layer and the level of global warming (Council Directive, 2003; Regulation, 2011; Regulation (EC), 2011; The Law of Ukraine, 2018, 2019b).

2) Atmospheric air quality. To implement the provisions of Directive 2008/50/EC and Directive 2004/107/EC (Directive 2004/107/EC..., 2004; Directive 2008/50/EC..., 2008) the Procedure for state monitoring in the field of air protection was approved, which makes provision for reform of the existing air monitoring system, as the current system does not allow to fully obtain operational information on concentrations of pollutants in the air and take timely measures to protect the population and the environment from their negative impact (Cabinet of Ministers of Ukraine, 2018). The order of the Ministry of Economic Development No. 1394 "On approval of the Technical Regulation on limiting emissions of volatile organic compounds due to the use of organic solvents in paints and varnishes for buildings and repair of wheeled vehicles" of 02.10.2018 was registered in the Ministry of Justice of Ukraine on October 30, 2018 under No. 1228/32680 (The Law of Ukraine "On Approval..., 2018). Order No. 62 of the Ministry of Ecology and Natural Resources of Ukraine "On Amendments to the Order of the Ministry of Environment No. 541of October 22, 2008" of February 16, 2018 (About the introduction of changes..., 2018) makes provision for the establishment of current and future technological standards of permissible emissions of pollutants into the atmosphere from existing stationary heat installations. Promising technological standards for permissible emissions of pollutants for existing plants are set taking into account the requirements of the National Plan for Reducing Emissions from Large Combustion Plants, approved by the Order of the Cabinet of Ministers of Ukraine No. 796 of November 8, 2017 (The National Plan for Reducing Emissions from Large Combustion Plants 2017).

3) Waste and resource management. To implement the provisions of the National Strategy for Waste Management in Ukraine until 2030, approved by the 
Order of the Cabinet of Ministers of Ukraine No. 820-r of November 8, 2017 (On approval of the National Waste..., 2017), the relevant Coordination Council was established for the period up to 2030, acting as a temporary advisory body to the Cabinet of Ministers of Ukraine to ensure coordinated actions of central and local executive bodies on the development and implementation of national policy in the field of waste management. The National Waste Management Plan until 2030 has been approved, which makes provision for the development of several draft laws, in particular regarding waste management, packaging waste, spent batteries and accumulators, waste from electrical and electronic equipment, etc. (The National Waste Management Plan, 2017).

Thus, it is safe to say that the legal aspect of the relationship between economic development and environmental pressures is significant, and at the legislative level this issue is largely addressed. However, the process of compliance with legal provisions and regulations by entrepreneurs, who usually try to avoid the issue of environmental protection in their private interests, remains an urgent problem, as it is not a profitable moment for them.

\section{CONCLUSIONS}

At present, the problem of the impact of economic development of the world on the state of the environment is very relevant. Entrepreneurs usually defend their private interests and try to increase profits in every possible way, without caring about the state of the environment and the future. While in the economically developed countries of the world the government is trying hard to control compliance with environmental legislation and implement a green economy, Ukraine is hopelessly behind in this regard, and only in recent years has been actively thinking about preserving the environment and developing mechanisms to achieve this goal. It was important to explore how the legal aspect can help address the balance between Ukraine's economic development and environmental quality, especially in terms of climate change impacts, where air pollution, waste generation, and energy security play a key role.

As a result of the study, the world experience in finding ways of mutually beneficial activities for the economic development of countries and the preservation of the environment was analysed. Factors influencing climate change, waste generation, and energy security in the projection of economic development were identified. The main principles (strategy) of the national ecological policy of Ukraine for the period up to 2030 were analysed, as well as the regulations of Ukraine and the European Union, which regulate the preservation of the environment in terms of the legal effect on solving the problem of the interrelation of economic growth and pressure on the environment. Further development of the study is seen in a more detailed consideration of the problem of energy security of Ukraine. In addition, an important strategic task is to develop recommendations for improving the work of executive bodies, for compliance of enterprises with provisions and legal bases of environmental legislation upon the economic development of such enterprises.

\section{REFERENCES}

Cabinet of Ministers of Ukraine. 2018. The procedure for the implementation of state monitoring in the field of atmospheric air protection. Cabinet of Ministers of Ukraine Decree dated August 12, 2018 No. 827. 2018. https://zakon.rada.gov.ua/laws/show/8272019-п\#n18.

Council Directive. 2003. Council Directive 2003/87/EC of 13 October 2003 establishing a scheme for greenhouse gas emission allowance trading within the Community and amending Council Directive 96/61/EC. 2003 https://mepr.gov.ua/files/docs/2003\%2087\%20 EC.pdf.

Dai, F., J. Liu and L. Liang. 2013. Industry segmentation under environmental pressure: an optimal approach. Technological and Economic Development of Economy, 19: S524-S543.

Danylyshyn, B. and O. Veklych. 2008. The effect of decoupling as the factor of the relationship between economic growth and environmental pressures. Visnyk NAN Ukrainy (Bulletin of the NAS of Ukraine), 5: 12-18.

Goroshkova, L. A., E. V. Khlobistov and V. O. Trofimchuk. 2019. The relationship between economic growth and the assimilation potential of the environment in ensuring sustainable development of national farms. , 1(69): 24-37. Project Management and Production Development, 1: 24-37.

Hatfield-Dodds, S., H. Schandl, P. D. Adams, T. M. Baynes, T. S. Brinsmead, B. A. Bryan, F. H. Chiew, P. W. Graham, 
M. Grundy and T. Harwood. 2015. Australia is 'free to choose'economic growth and falling environmental pressures. Nature, 527: 49-53.

James, D. W., C. S. Paul, A. D. Werner, R. Costanza, S. H. Mohr and C. T. Simmons. 2016. Is Decoupling GDP Growth from Environmental Impact Possible? , 11(10): 0164733. Public Library of Science ONE, 11: 0164733.

Khvesyk, M. A. and A. V. Stepanenko. 2014. Ecologic crisis in Ukraine: social and economic consequences and the ways of its overcoming. , 1 : 74-85. Economic Problems of Nature Management, 1.

Kyshko-Yerli, 0. 2014. Adaptation of Ecology Law of Ukraine for European Union Environmental Law. , 3: 215-19. Journal of Kyiv University of Law, 3: 215-219.

Moroz, G. V. 2019a. A group lawsuit as a means of protecting the right to a safe and healthy environment: perspectives for implementation. Visegrad Jurnal on Human Rights, 5: 125-130.

Moroz, G. V. 2019b. The essence of legal restrictions in environmental law. Scientific and Information Bulletin of Ivano-Frankivsk University of Law named after King Danylo Halytsky, 8: 142-150.

Moroz, G. V. 2020. Institutionalization of interests in the context of ensuring the ecological function of the state. Journal of Kyiv University of Law, 1: 270-273.

Regulation. 2011. Regulation 842/2006/EC of 17 May 2006 on certain fluorinated greenhouse gases. 2011.

https://mepr.gov.ua/files/docs/842\%202006\%2 0EC.pdf.

Regulation (EC). 2011. Regulation (EC) No 2037/2000 on substances that deplete the ozone layer. 2011. https://mepr.gov.ua/files/docs/2037\%202000.pdf.

Schandl, H., S. Hatfield-Dodds, T. Wiedmann, A. Geschke, Y. Cai, J. West, D. Newth, T. Baynes, M. Lenzen and A. Owen. 2016. 2016. Decoupling global environmental pressure and economic growth: scenarios for energy use, materials use and carbon emissions. 132: 45-56. . Journal of Cleaner Production, 132: 45-56.

Senyshyn, O. S. and M. S. Senyshyn. 2017. Organizational and institutional bases of the state protection targeted programming of natural environment in Ukraine. Scientific Bulletin of Uzhhorod National University, 14: 114-118.
Sotnyk, I. and L. Kulyk. 2014. Decoupling analysis of economic growth and environmental impact in the regions of Ukraine. Economics of Natural Resources and Environmental Protection, 7-8: 6064.

State Climate Change Policy. 2016. The Concept of State Climate Change Policy Implementation until 2030. Cabinet of Ministers of Ukraine Decree dated December 7, 2016 No. 932-p. 2016. https://www.kmu.gov.ua/npas/249573705.

The Law of Ukraine. 2017. The Law of Ukraine "On the assessment of fuel consumption" dated May 23, 2017 No. 2059-VIII. Official portal of the Verkhovna for the sake of Ukraine. 2017. http://zakon2.rada.gov.ua/laws/show/2059-19.

The Law of Ukraine. 2018. The Law of Ukraine "On Approval of the Technical Regulations for the Limitation of Emissions of Volatile Organic Compounds due to the Use of Organic Solvents in Paints and Varnishes for Buildings and Repair of Wheeled Vehicles" dated February 10, 2018 No. 1394.

2018.

https://zakon.rada.gov.ua/laws/show/z122818\#Text.

The Law of Ukraine. 2019a. The Law of Ukraine "On regulation of economic activity with ozonedepleting substances and fluorinated greenhouse gases" dated December 12, 2019, No. 376-IX. 2019. https://zakon.rada.gov.ua/laws/show/37620\#Text.

The Law of Ukraine. 2019b. The Law of Ukraine "On the Basic Ambush (Strategy) of the State Ecological Policy of Ukraine for the Period until 2030" 28.02.2019 № 2697-VIII. 2019. https://ips.ligazakon.net/document/view/t19269 7? $\mathrm{an}=1$.

The Low Carbon Development Strategy of Ukraine. 2016. The Low Carbon Development Strategy of Ukraine until 2050.2016. https://mepr.gov.ua/files/docs/Proekt/LEDS ua l ast.pdf.

The National Plan for Reducing Emissions from Large Combustion Plants 2017. The National Plan for Reducing Emissions from Large Combustion Plants dated November 8, 2017, No. 796. 2017. https://zakon.rada.gov.ua/laws/show/796-2017p\#Text. 
The National Waste Management Plan. 2017. The National Waste Management Plan until 2030. Cabinet of Ministers of Ukraine Decree dated November 8, 2017, No. 820-p. 2017. https://zakon.rada.gov.ua/laws/show/820-2017p\#Text.

Yadong, Y., Z. Li., Z. Wenji, H. Ren, A. Kharrazi, T. Ma and B. Zhu. 2017. Decoupling environmental pressure from economic growth on city level: The Case Study of Chongqing in China. Ecological Indicators, 75: 27-35.

Yakushev, D. 2016. Current trends in state environmental policy in Ukraine in the context of the concept of sustainable development. Public Administration and Local Self-Government, 4: 92-97.

Publisher's note: EScience Press remains neutral with regard to jurisdictional claims in published maps and institutional affiliations.

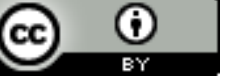

Open Access This article is licensed under a Creative Commons Attribution 4.0 International License, which permits use, sharing, adaptation, distribution and reproduction in any medium or format, as long as you give appropriate credit to the original author(s) and the source, provide a link to the Creative Commons license and indicate if changes were made. The images or other third-party material in this article are included in the article's Creative Commons license, unless indicated otherwise in a credit line to the material. If material is not included in the article's Creative Commons license and your intended use is not permitted by statutory regulation or exceeds the permitted use, you will need to obtain permission directly from the copyright holder. To view a copy of this license, visit http://creativecommons.org/licenses/by/4.0/. 